\title{
Detecting Temporal Change in Watershed Nutrient Yields
}

\author{
James D. Wickham · Timothy G. Wade • \\ Kurt H. Riitters
}

Received: 9 August 2007/ Accepted: 15 March 2008/Published online: 30 April 2008

(C) Springer Science+Business Media, LLC 2008

\begin{abstract}
Meta-analyses reveal that nutrient yields tend to be higher for watersheds dominated by anthropogenic uses (e.g., urban, agriculture) and lower for watersheds dominated by natural vegetation. One implication of this pattern is that loss of natural vegetation will produce increases in watershed nutrient yields. Yet, the same meta-analyses also reveal that, absent land-cover change, watershed nutrient yields vary from one year to the next due to many exogenous factors. The interacting effects of land cover and exogenous factors suggest nutrient yields should be treated as distributions, and the effect of land-cover change should be examined by looking for significant changes in the distributions. We compiled nutrient yield distributions from published data. The published data included watersheds with homogeneous land cover that typically reported two or more years of annual nutrient yields for the same watershed. These data were used to construct statistical models, and the models were used to estimate changes in the nutrient yield distributions as a result of land-cover change. Land-cover changes were derived from the National Land Cover Database (NLCD). Total nitrogen (TN) yield distributions increased significantly for 35 of 1550 watersheds and decreased significantly for 51 . Total phosphorus (TP) yield
\end{abstract}

J. D. Wickham $(\varangle) \cdot$ T. G. Wade

National Exposure Research Laboratory, U.S. Environmental

Protection Agency (E243-05), Research Triangle Park,

NC 27711, USA

e-mail: wickham.james@epa.gov

T. G. Wade

e-mail: wade.timothy@epa.gov

\section{K. H. Riitters}

Southern Research Station, U.S. Forest Service, 3041 Cornwallis

Road, Research Triangle Park, NC 27709, USA

e-mail: kriitters@fs.fed.us distributions increased significantly for 142 watersheds and decreased significantly for 17 . The amount of land-cover change required to produce significant shifts in nutrient yield distributions was not constant. Small land-cover changes led to significant shifts in nutrient yield distributions when watersheds were dominated by natural vegetation, whereas much larger land-cover changes were needed to produce significant shifts when watersheds were dominated by urban or agriculture. We discuss our results in the context of the Clean Water Act.

Keywords Clean Water Act · Change detection . Ecoregions · Eutrophication - Land cover · Nitrogen · Phosphorus

\section{Introduction}

Human use of the environment has altered the flux of nutrients from watersheds to receiving waterbodies. Howarth and others (1996) estimated a five- to 14-fold increase in nitrogen yield since the pre-industrial period for the major rivers of the northeastern United States. Rabalais and others (1996) have reported a two-fold increase in nitrate concentrations and a significant increase in phosphorus (inferred through changes in silica concentrations) for the Mississippi River since the early 1900s. These studies show that human activities related to agriculture and urbanization have increased watershed nutrient flux over the last 100-150 years.

Not surprisingly, the well-developed literature on the relationship between watershed land-cover composition and nitrogen $(\mathrm{N})$ and phosphorus $(\mathrm{P})$ yields shows a similar pattern. Annual $\mathrm{N}$ and $\mathrm{P}$ yields tend to be higher for watersheds dominated by agriculture or urban as compared 
to watersheds dominated by natural vegetation (Omernik 1977; Reckhow and others 1980; Frink 1991; Panuska and Lillie 1995; Fisher and others 1998). These studies suggest that watershed nutrient yields will increase as natural vegetation is replaced by urban and agriculture, and that such changes should be detectable over more contemporary time periods (e.g., 5, 10, 20 years). However, the detection of significant changes in watershed $\mathrm{N}$ and $\mathrm{P}$ yields as a result of land-cover change over more contemporary periods is complicated by the inter-annual variability in $\mathrm{N}$ and $\mathrm{P}$ yields attributable to other factors. Many of the same studies that show increases in $\mathrm{N}$ and $\mathrm{P}$ yields with decreases in natural vegetation also reveal that, absent land-cover change, $\mathrm{N}$ and $\mathrm{P}$ yields will vary from one year to the next (Reckhow and others 1980; Panuska and Lillie 1995; Dodds and others 1996; Fisher and others 1998) due to inter-annual changes in annual precipitation totals, cropping practices, and other factors. For example, Panuska and Lillie (1995) reported approximately a 15 -fold range in phosphorus yields $(0.15-$ $2.45 \mathrm{~kg} / \mathrm{ha} / \mathrm{yr}$ ) for the White Creek watershed in Wisconsin between 1981 and 1988, and Fisher and others (1998) reported approximately 4-fold ranges in $\mathrm{N}(2.89-11.50 \mathrm{~kg} /$ ha/yr) and $\mathrm{P}(0.14-0.65 \mathrm{~kg} / \mathrm{ha} / \mathrm{yr})$ for the upper Choptank watershed in Maryland between 1981 and 1990. Comparison of available land-cover data from ca. 1980 (Fegeas and others 1983) and ca. 1992 (Vogelmann and others 2001) suggests that neither watershed experienced much landcover change over their respective reporting periods. Intrasite, inter-annual variability in watershed $\mathrm{N}$ and $\mathrm{P}$ yields suggests they should be treated as a distribution instead of as a mean value, and the effect of land-cover change should be gauged by its effect on the distribution of yields.

The effect of land-cover change on $\mathrm{N}$ and $\mathrm{P}$ distributions has not been studied extensively. One reason may be that empirical studies of land cover/nutrient relationships often pool $\mathrm{N}$ and $\mathrm{P}$ observations over several years to improve model fit (e.g., Hunsaker and Levine 1995; Smith and others 1997; Alexander and others 2000; Jones and others 2001; McFarland and Hauck 2001; Lewis 2002; McMahon and others 2003). Process-based models can be used to study the effect of land-cover change on $\mathrm{N}$ and $\mathrm{P}$ distributions, but extensive data requirements may explain why such efforts do not appear to be common. The Soil Water Assessment Tool (SWAT) (Arnold and others 1998) and Hydrologic Simulation Program-Fortran (HSPF) (USEPA 1997) are two widely-used process-based models for the study of watershed nutrient flux (Donigian and Imhoff 2002; Gassman and others 2007). Very few of the hundreds of SWAT applications reviewed by Gassman and others (2007) focused on land-cover change, and those that did restricted their focus to hydrologic impacts. Shenk and Linker (unpublished) point out that calibration of the HSPF model typically requires many years of in-stream monitoring data and therefore does not incorporate landcover change well. Shenk and Linker (unpublished) modified the HSPF code so the model could estimate nutrients as a function of land cover at two points in time, but did not disaggregate the nutrient data into matching temporal periods. Even if placed in a temporal context, empirical and process models may not be able to gauge the effect of land-cover change simply by comparing model output for two points in time, because it would be difficult to gauge the significance of nutrient yield changes from $T_{1}$ to $T_{2}$ without knowledge of the inherent variability at $T_{1}$. The few studies that have examined the effect of land-cover change on nutrient yield have not been undertaken from the perspective that $T_{1}$ and $T_{2}$ output represent points in a wider distribution, and therefore could not fully assess the impact of land-cover change on nutrient yield (e.g., Vuorenmaa and others 2002).

The two objectives of this article are: (1) to develop a dataset of nutrient yields that incorporates intra-site, interannual variability using watersheds dominated by a single land-cover class (e.g., forest, urban), and (2) use the dataset to show the effect of land-cover change on the distribution of TN and TP yields. The two objectives are related to water-quality management prescribed under the Clean Water Act (P.L. 92-500), which maintains water quality through the use of standards (http://www.epa.gov/ waterscience/standards). Water-quality standards have three components: designated use, criteria, and anti-degradation. Individual states establish designated uses (e.g., fishing, swimming, drinking), numerical criteria serve as benchmarks to determine if designated uses are being met, and anti-degradation policies are put in place to maintain and protect the established designated uses. Quantifying the affect of land-cover change on $\mathrm{N}$ and $\mathrm{P}$ distributions can be used to guide development and interpretation of $\mathrm{N}$ and P criteria (USEPA 1998) and antidegradation policies.

\section{Methods}

The following steps were used to determine the effect of land-cover change on watershed $\mathrm{N}$ and $\mathrm{P}$ yields: (1) total nitrogen (TN) and phosphorus (TP) yields were compiled from the literature for watersheds dominated by forest, urban, agriculture, and grass or shrub (i.e., range); (2) the land-cover specific TN and TP data were fit to statistical distributions to provide models of TN and TP yield by land-cover class, and (3) temporal land-cover data from the National Land Cover Database (NLCD) (http://www. mrlc.gov, http://www.epa.gov/mrlc/change.html) were used to determine the effect of land-cover changes on $\mathrm{TN}$ and TP by applying the statistical models for time $1\left(\mathrm{~T}_{1}\right)$ 
(ca. 1992) and time $2\left(\mathrm{~T}_{2}\right)$ (ca. 2001) watershed landcover compositions. We used the Watershed Boundary Dataset (WBS) 12-digit hydrologic units for the state of North Carolina to summarize $\mathrm{T}_{1}$ and $\mathrm{T}_{2}$ land-cover compositions and compare $\mathrm{T}_{1}$ and $\mathrm{T}_{2} \mathrm{TN}$ and $\mathrm{TP}$ yields. The 12-digit hydrologic units, which are much smaller than the 8-digit hydrologic units available for the conterminous United States, are being developed to better address water resource analysis and management issues (FGDC 2004). We focused on TN and TP because they are commonly reported in the literature, and they have been recommended for establishing nutrient criteria for ecological endpoints (Dodds and Welch 2000). Only TN and TP literature values for watersheds dominated by a single land-cover class were used in order to improve the accuracy of the estimates of the effect of land-cover change on TN and TP yields. We used a threshold of $80 \%$ to define dominance. Preliminary analyses were conducted to test for confounding effects due to time, source, and geographic location prior to fitting the data to statistical distributions.

\section{Compilation of $\mathrm{N}$ and $\mathrm{P}$ Data from Literature Sources}

TN and TP literature sources included Reckhow and others (1980), Clesceri and others (1986), Panuska and Lillie (1995), Jordan and others (1997), McFarland and Hauck (2001), Line and others (2002), and Groffman and others (2004). All of these sources reported TN and TP yields for watersheds with homogenous land cover, and all except for Line and others (2001) and McFarland and Hauck (2001) reported TN, TP, or both for multiple years for one or more watersheds. TN and TP yields reported in the often cited Beaulac and Reckhow (1982) publication are summaries developed from Reckhow and others (1980).

The literature sources were augmented with U.S. Geological Survey (USGS) data from the Water Quality Network (WQN) (USGS 1996; Alexander and others 1998). The WQN data include two main groups of sampling sites: the National Stream Quality Accounting Network (NASQAN) and the Historical Benchmark Network (HBN). HBN sites are considered reference or "pristine," with little anthropogenic influence (Smith and others 2003). WQN data are organized by year, generally ranging from the early 1970 s to about 1995 , but very few sites had observations for all years. A site characteristics file in the database provided geographic locations and landcover proportions for each watershed. That file was used to screen the entire dataset for watersheds dominated by a single land-cover class. We then created watershed boundaries for each WQN site included in our dataset using the National Elevation Data (NED) (Gesch and others 2002). Land-cover compositions were confirmed using the
2001 National Land Cover Database (NLCD 2001) (http:// www.mrlc.gov; Homer and others 2007).

WQN concentration $(\mathrm{mg} / \mathrm{L})$ and flow $(\mathrm{L} / \mathrm{sec})$ data were used to develop nutrient yields. TN concentrations were used only if there were matching observations for both total nitrate-nitrogen $\left(\mathrm{TNO}_{3}\right)$ and total Kjeldahl nitrogen (TKN). Conversion of concentrations to yields followed Lewis (2002). Days with concentration values served as midpoints, and all intervening days were assigned the concentration value of the closest day. There had to be at least one concentration observation in each season for a given year to be used (Winter: December-February, Spring: March-May, Summer: June-August, Fall: September-November). We imposed this seasonal requirement because Fisher and others (1998) found seasonal patterns in nutrient concentrations. The product of concentration and flow were converted to annual yields $(\mathrm{kg} / \mathrm{ha} / \mathrm{yr})$ using the appropriate conversion factors.

Our final dataset included 1228 observations spread across 167 sites, but TN and TP estimates were not available for every observation (i.e., site $x$ year). The WQN data comprised 1024 of the observations, and the other literature sources contributed 204 additional observations. The sites are distributed across the conterminous United States and southern Canada (Fig. 1a), and there is generally good geographic dispersion of the sites when organized by dominant land-cover class (Fig. 1b). Watersheds classified as range are, not surprisingly, concentrated in the west.

Once compiled, the TN and TP yield data were tested for potentially confounding effects due to source (e.g., WQN versus other literature), geographic location, and time. ANOVA methods were used to determine if mean TN and TP yields differed by source. Sources were excluded from the ANOVA analysis if there were too few observations. The observations from these sources were kept if they did not alter the TN or TP minima or maxima. The effect of geographic location was tested using nutrient ecoregions (USEPA 1998; Rohm and others 2002). A nested ANOVA was used to test for an ecoregional effect on nutrient yield after accounting for the effect of land cover (Wickham and others 2005). Time was tested by plotting and regressing annual yields versus year on a per nutrient per site basis. Analysis of the effect of time was restricted to watersheds with at least 10 years of TN or TP observations.

\section{$\mathrm{N}$ and $\mathrm{P}$ Statistical Distributions}

The TN and TP empirical distributions (Table 1A) were fit to normal, log-normal, exponential, and Weibull statistical distributions. Log-normal distributions were found to provide the best fit across all eight cases of land-cover class and nutrient (Table 1B). Goodness-of-fit for normal and 

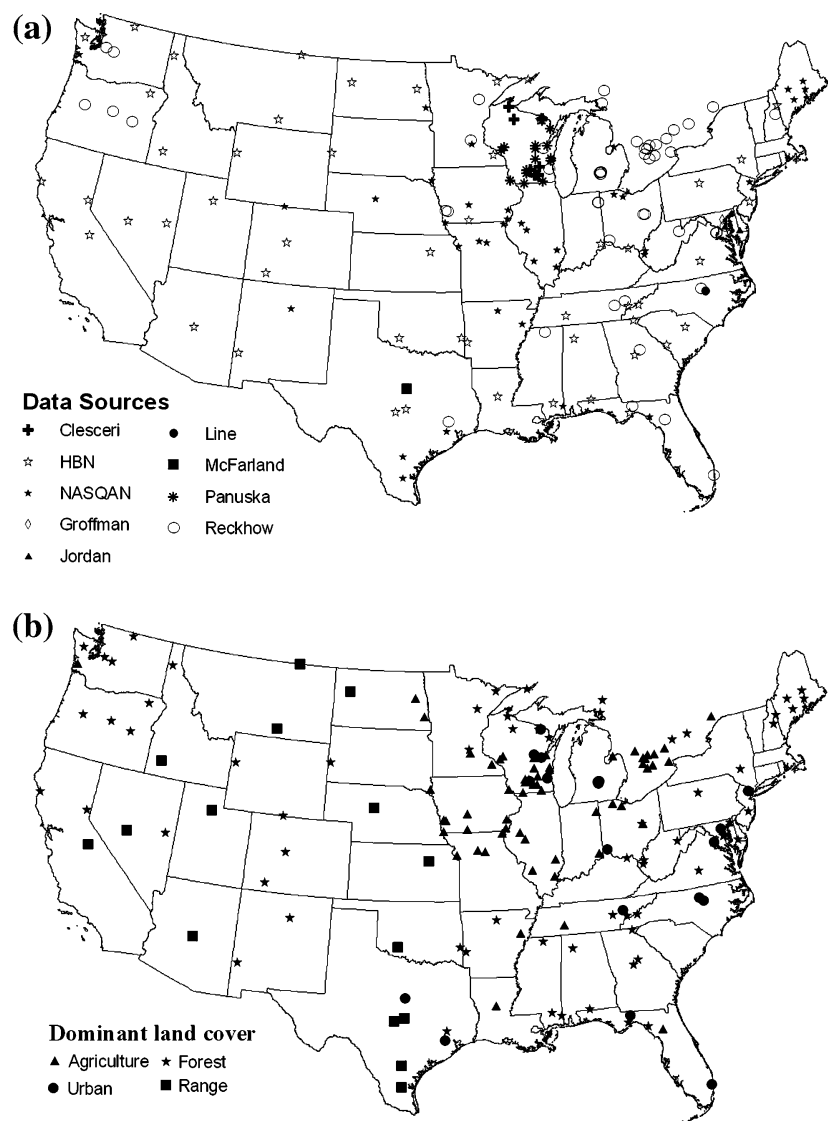

Fig. 1 Geographic distribution of samples sites by source (a) and dominant land cover (b). Locations are approximate for sites not in the USGS network

exponential distributions were uniformly poor across all eight cases. Weibull distributions did not represent extreme values as well as log-normal distributions. These results are consistent with those reported by Wickham and others (2000).

\section{Land-Cover Change and Nutrient Yield Modeling}

The NLCD (http://www.mrlc.gov, http://www.epa.gov/ $\mathrm{mrlc} / \mathrm{change} . \mathrm{html}$ ) was used to estimate land-cover change. The NLCD change data provide pixel-by-pixel change for the NLCD 1992 (Vogelmann and others 2001) and the NLCD 2001 (Homer and others 2007) land-cover data. The classes in the land-cover change dataset include forest, urban, agriculture, shrub/grass (range), water, wetland, barren, and all realized changes among the seven classes (e.g., forest to urban). These data were used to develop separate $T_{1}$ (ca. 1992) and $T_{2}$ (ca. 2001) landcover composition estimates for each WBD 12-digit watershed in North Carolina. The shrub/grass category was used to define range. Pasture is included in agriculture.

Monte Carlo methods were used to simulate TN and TP distributions after deriving $\mathrm{T}_{1}$ and $\mathrm{T}_{2}$ land-cover compositions for each watershed (Wickham and others 2000). At each iteration (per watershed), $\mathrm{TN}$ or TP values drawn for each land-cover class (Table 1B) were multiplied by the proportion of the class in the watershed and then summed to derive a weighted average for the iteration. The model was iterated 10,000 times for each watershed at each date to derive TN and TP distributions. Correlation was built into the modeling so that the random draws for a given iteration came from the same points in the lognormal distributions for each land-cover class. Correlation was necessary to enforce similar "behavior" across all landcover classes for a given iteration. Watersheds respond similarly to dry and wet years regardless of land-cover composition, producing low and high yields, respectively (Panuska and Lillie 1995; Fisher and others 1998). Correlation was needed so that a high value of TN or TP for one land-cover class did not co-occur with a low value for another land-cover class in the same iteration.

We tested for significant change in $\mathrm{T}_{1}$ and $\mathrm{T}_{2} \mathrm{TN}$ and TP distributions by comparing the change (per watershed) to the stochastic variability in the model (Wickham and others 2002). Stochastic variability was estimated by running the model for a hypothetical watershed comprised of 50\% forest and 50\% range. The model was run 100 times (10,000 replicates per run), and the ranges for the median $\left(\mathrm{P}_{50}\right)$ and 90th percentile $\left(\mathrm{P}_{90}\right)$ were computed from the 100 runs. The $\mathrm{P}_{50}$ and $\mathrm{P}_{90}$ ranges, expressed as proportions ([max.-min. $] / \min$.), were used as significance thresholds. The $\mathrm{P}_{50}$ and $\mathrm{P}_{90}$ significance thresholds for $\mathrm{TN}$ were 0.05 and 0.08 , respectively, and their counterparts for TP were 0.06 and 0.09 , respectively. The difference between watershed $T_{1}$ and $T_{2} P_{50}$ and $P_{90}$ values, also expressed as proportions, had to be greater than or equal to the significance thresholds to be considered different.

\section{Results}

There were no confounding effects in the nutrient yield data. Twenty USGS stations had at least 10 years of observations for $\mathrm{TN}$, and 55 stations had at least 10 years of observations for TP. There were no unequivocal temporal trends in the nutrient data. Source effects were similarly insignificant (Table 2). There were no significant differences for either TN or TP among sources (e.g., USGS versus Reckhow and others 1980) for any land-cover class. Ecoregions were likewise not a significant determinant of nutrient yield (Table 3 ). The ecoregional results are consistent with previous evaluations; ecoregions do not explain differences in nutrient yields (or concentrations) (Dodds and Oakes 2004; Wickham and others 2005). However, TN and TP were significantly different when compared by land-cover class (results not shown, but see 
Table 1 Observed data (A), and TN and TP lognormal parameters and goodness-of-fit estimates (B)

\begin{tabular}{|c|c|c|c|c|c|c|c|c|}
\hline A. Class & Nutrient & Number of observations & & $\mathrm{P}_{25}$ & & $\mathrm{P}_{50}$ & $\mathrm{P}_{75}$ & $\mathrm{P}_{95}$ \\
\hline Agriculture & $\mathrm{TN}$ & 276 & & 6.123 & & 11.926 & 22.462 & 41.750 \\
\hline Developed & $\mathrm{TN}$ & 60 & & 6.300 & & 9.250 & 12.445 & 28.830 \\
\hline Forest & $\mathrm{TN}$ & 199 & & 1.579 & & 2.447 & 3.379 & 8.052 \\
\hline Range & $\mathrm{TN}$ & 59 & & 0.163 & & 0.564 & 0.957 & 3.120 \\
\hline Agriculture & $\mathrm{TP}$ & 392 & & 0.290 & & 0.680 & 1.279 & 2.196 \\
\hline Developed & $\mathrm{TP}$ & 56 & & 0.776 & & 1.385 & 3.095 & 5.852 \\
\hline Forest & $\mathrm{TP}$ & 582 & & 0.051 & & 0.089 & 0.177 & 0.501 \\
\hline Range & $\mathrm{TP}$ & 124 & & 0.019 & & 0.059 & 0.147 & 0.307 \\
\hline B. Class & Nutrient & Threshold & Scale & & Shape & \multicolumn{2}{|r|}{ Kolmogorov D } & $\operatorname{Pr}>D$ \\
\hline Agriculture & $\mathrm{TN}$ & -3.60 & 2.70 & & 0.70 & \multicolumn{2}{|r|}{0.0418} & 0.7117 \\
\hline Developed & $\mathrm{TN}$ & 0.00 & 2.20 & & 0.55 & \multicolumn{2}{|r|}{0.0538} & 0.9922 \\
\hline Forest & $\mathrm{TN}$ & -0.20 & 0.96 & & 0.70 & \multicolumn{2}{|r|}{0.0618} & 0.4255 \\
\hline Range & $\mathrm{TN}$ & 0.003 & -0.80 & & 1.30 & \multicolumn{2}{|r|}{0.1036} & 0.5286 \\
\hline Agriculture & $\mathrm{TP}$ & -0.10 & -0.30 & & 0.88 & \multicolumn{2}{|r|}{0.0347} & 0.7249 \\
\hline Developed & $\mathrm{TP}$ & 0.0372 & 0.373 & & 0.937 & \multicolumn{2}{|r|}{0.0852} & 0.8130 \\
\hline Forest & $\mathrm{TP}$ & 0.0 & -2.40 & & 0.925 & \multicolumn{2}{|r|}{0.0319} & 0.5869 \\
\hline Range & $\mathrm{TP}$ & 0.0 & -2.90 & & 1.30 & \multicolumn{2}{|r|}{0.0635} & 0.6861 \\
\hline
\end{tabular}

Units for percentiles (e.g., $\mathrm{P}_{25}$ ) are $\mathrm{kg} / \mathrm{ha} / \mathrm{yr}$

Table 2 Effect of source on TP yield

\begin{tabular}{llll}
\hline & $\begin{array}{l}\text { Panuska and } \\
\text { Lillie (1995) }\end{array}$ & $\begin{array}{l}\text { Reckhow and } \\
\text { others (1980) }\end{array}$ & $\begin{array}{l}\text { USGS WGN } \\
(1998)\end{array}$ \\
\hline $\begin{array}{c}\text { Panuska and } \\
\text { Lillie (1995) }\end{array}$ & 0.2414 & 0.1798 \\
$\begin{array}{c}\text { Reckhow and } \\
\text { others (1980) }\end{array}$ & & & 0.1248 \\
\hline
\end{tabular}

Cell entries are $p$-values for least square means test. Source-effect comparisons for all nutrient by land-cover class combinations produced similar results

Table 1A). ANOVA results indicated that watersheds dominated by agriculture, urban, forest, and range were significantly different in terms of nutrient yields, except for forest versus range. We chose to treat forest and range as distinct despite the lack of statistical significance. There was a noticeable empirical difference in the distributions, and, to our knowledge, this is the first nutrient yield dataset that distinguishes range from other land-cover classes (see Reckhow and others 1980; Frink 1991).

As expected, loss of natural vegetation in the watershed produced increases in TN and TP yields, and gains produced decreases. Land-cover change resulted in a significant increase in the distribution of TN yields for 35 of approximately 1550 (approximately 2.0\%) watersheds and significant decrease in the distribution of TN yields for 51 watersheds (Fig. 2a). The effect of land-cover change
Table 3 Ecoregional effects on nutrient export

\begin{tabular}{lrrccr}
\hline & DF & $\begin{array}{c}\text { Sum of } \\
\text { squares }\end{array}$ & $\begin{array}{l}\text { Mean } \\
\text { square }\end{array}$ & $F$-value & $p$-value \\
\hline Nitrogen & & & & & \\
Model & 27 & 24272.08 & 898.97 & 13.11 & $<0.0001$ \\
$\quad$ Ecoregion & 12 & 3020.62 & 251.71 & $0.98^{\mathrm{a}}$ & 0.5014 \\
$\quad$ Land cover & 15 & 5615.06 & $274.34^{\mathrm{a}}$ & 5.46 & $<0.0001$ \\
Error & 554 & 37987.89 & & & \\
Corrected total & & 62259.97 & & & \\
Phosphorus & & & & & \\
Model & 26 & 502.42 & 19.23 & 39.81 & $<0.0001$ \\
$\quad$ Ecoregion & 12 & 116.71 & 9.73 & $0.91^{\mathrm{b}}$ & 0.5587 \\
$\quad$ Land cover & 14 & 148.27 & $10.59^{\mathrm{b}}$ & 21.82 & $<0.0001$ \\
Error & 1106 & 536.79 & 0.49 & & \\
Corrected total & 1132 & 1039.20 & & & \\
\hline
\end{tabular}

${ }^{a}$ The adjusted mean squares for land cover are 68.57 and 0.485

b The adjusted degrees of freedom are 18.59 and 13.99

on TP was more dramatic. Land-cover change resulted in a significant increase in the distribution of TP yields for 142 of approximately 1550 (approximately 9.0\%) watersheds, and significant decrease in the distribution of TP yields for only 17 watersheds (Fig. 2b).

Change in TP distributions had an urban signal. Many of the watersheds with significant changes in TP distributions surround the state's major urban centers. Urban TP yields 
(a)

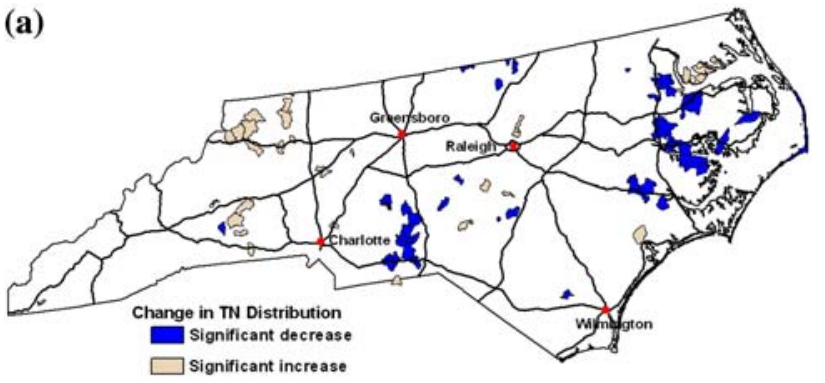

(b)

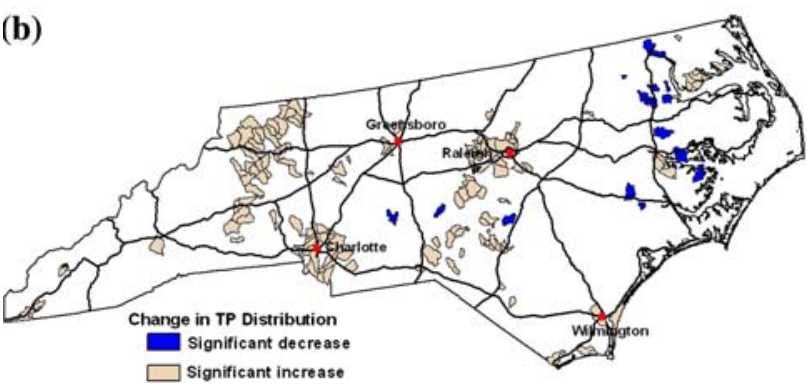

Fig. 2 Watersheds with significant increases and decreases in TN (a) and TP (b) as a result of land-cover change. Major roads and cities are overlaid for geographic orientation

in our dataset are generally an order of magnitude greater than TP yields for the two natural vegetation classes. The differences in TN yield between urban and the two natural vegetation classes, while large, were not quite as dramatic. Thus, smaller amounts of urban growth were needed to change TP distributions significantly. The observed data (Table 1A) suggest that urbanization will result in substantial increases in phosphorus yield.

The influence of organic nitrogen (i.e., total Kjeldahl nitrogen $[\mathrm{TKN}]$ ) on $\mathrm{TN}$ yields for forest and range may explain why TN was less sensitive to urbanization than TP and why fewer watersheds showed significant changes in TN distributions than TP distributions. When forest and range $\mathrm{TN}$ values were high (e.g., $\mathrm{P}_{90}$ ), it was generally because of very high TKN values. A higher ratio of organic to inorganic forms of nitrogen for watersheds dominated by natural vegetation is consistent with other studies (e.g., Kemp and Dodds 2001). Replacing TN with nitrate-nitrogen $\left(\mathrm{TNO}_{3}-\mathrm{N}\right)$ in our analysis likely would have produced more distinct differences in the empirical distributions for nitrogen between the natural vegetation and anthropogenic classes, which in turn may have produced results for nitrogen that were more similar to those for TP.

Significant changes in TN and TP yield were dependent on the amount of natural vegetation in the watershed (Fig. 3). Small losses of natural vegetation produced significant increases in the distributions of TN and TP yields when natural vegetation dominated the watershed, whereas larger changes in the amount of natural vegetation were needed to produce significant changes in $\mathrm{TN}$ and $\mathrm{TP}$

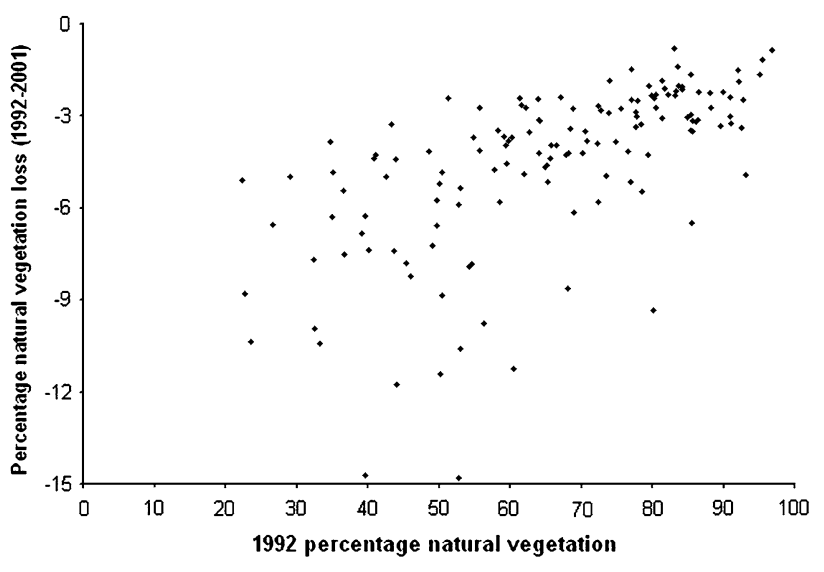

Fig. 3 Relationship between $T_{1}$ percentage of natural vegetation and change in natural vegetation for watersheds with significant increases in TP distribution. The points displayed represent the tan-colored watersheds in Fig. 2b

distributions when the watershed was dominated by urban or agriculture at $T_{1}$. The nonconstant relationship between nutrient yield and land-cover change is expressed geographically in Fig. 2. The significant increases in TN and TP distributions in western North Carolina were the result of relatively small losses of forest in forest-dominated watersheds. The amount of natural vegetation loss in these watersheds was generally small, but even small losses of natural vegetation produced significant changes TN and TP in distributions.

The nonconstant relationship between significant changes in $\mathrm{T}_{1}$ and $\mathrm{T}_{2} \mathrm{TN}$ and TP distributions and land-cover change is perhaps best explained by the box plots of nutrient yield by land-cover class in the often cited Beaulac and Reckhow publication (1982). The box plots show that shifting a watershed's dominant land cover from natural vegetation to urban or agriculture increases the variance in $\mathrm{TN}$ and TP yields, not just the means. Higher rates of TN and TP change are needed to produce significant changes in TN and TP distributions when the distributions are already variable. Conversely, when variability in TN and TP distributions is small (i.e., watersheds dominated by natural vegetation), comparatively little change is needed to shift the distributions significantly.

\section{Discussion}

Watershed land-cover composition is recognized as one of the dominant drivers of watershed nutrient yield. Landcover composition is routinely found to be a significant factor in empirical studies (e.g., Hunsaker and Levine 1995; Jones and others 2001; Dodds and Oakes 2004; Wickham and others 2005), several meta-analyses report distinct differences in nutrient yields by dominant land cover 
(Omernik 1977; Reckhow others 1980; Frink 1991; Panuska and Lillie 1995; Fisher and others 1998), and water-quality models use land-cover specific load coefficients $(\mathrm{kg} / \mathrm{ha} / \mathrm{yr})$ for estimation, calibration, and validation of nutrient yields (Shenk and Linker unpublished; Linker and others 1996). We used monitored data in a straightforward statistical model to determine the effect of watershed land-cover change on nutrient yields. The monitored data incorporated intra-site, inter-annual variability from watersheds with homogenous land cover to gauge the effect of land-cover change as accurately as possible.

The amount of land-cover change needed to significantly change TN and TP distributions were inversely related the $T_{1}$ percentage of natural vegetation in the watershed. Small losses of natural vegetation produced significant increases in TN and TP distributions when the amount of natural vegetation at $\mathrm{T}_{1}$ was high, whereas much higher losses of natural vegetation were needed to significantly change $\mathrm{TN}$ and $\mathrm{TP}$ distributions when the $\mathrm{T}_{1}$ percentage of natural vegetation was low. The increase in inter-annual variability of nutrient yields with increasing percentages of urban and agriculture suggests that watersheds become more sensitive to the exogenous factors that affect nutrient yields as natural vegetation is replaced by urban and agriculture. Agriculture- and urban-dominated watersheds are more sensitive to exogenous factors because they introduce novel sources of nutrients (fertilizers, septic tanks, waste-treatment facilities), build structures that convey nutrients to streams, such as tile drains and storm drains (Osborne and Kovacic 1993; Paul and Meyer 2001), and remove natural vegetation, which is a barrier to nutrient runoff (Peterjohn and Correl 1984; Waring and Schlesinger 1985). For example, all other factors being equal, a rainstorm in an agricultural watershed in early spring will produce greater nutrient runoff than the same storm later in the growing season because the crops have not had time to consume some of the nutrients in the fertilizer and there is little vegetation to retard runoff. Urbandominated watersheds have similar sensitivities. Wet springtime conditions will tend to produce greater nutrient runoff than drier springtime conditions in urbanized watersheds since lawn fertilization (both residential and commercial) is commonly a springtime activity. Similarly, leakage from septic systems will ebb and flow with changes in the water table. In contrast, watersheds dominated by natural vegetation are less sensitive to exogenous factors because they do not contain novel sources of nutrients and barriers to nutrient runoff have not been removed.

The relationship between land-cover change and nutrient yield change has implications for watershed management goals related to the Clean Water Act. Loss of natural vegetation will increase sensitivity to exogenous factors, making it more difficult to meet management goals such as
Table 4 Simulated changes in TN yields for hypothetical changes in land cover

\begin{tabular}{lllrl}
\hline Watershed & $\mathrm{P}_{25}$ & $\mathrm{P}_{50}$ & $\mathrm{P}_{75}$ & $\mathrm{IQR}$ \\
\hline $100 \% \mathrm{~F}$ & 1.46 & 2.98 & 3.89 & 2.43 \\
$80 \% \mathrm{~F}, 10 \% \mathrm{D}, 10 \% \mathrm{~A}$ & 2.41 & 4.02 & 6.52 & 4.11 \\
$60 \% \mathrm{~F}, 20 \% \mathrm{D}, 20 \% \mathrm{~A}$ & 3.32 & 5.52 & 8.93 & 5.61 \\
$40 \% \mathrm{~F}, 30 \% \mathrm{D}, 30 \% \mathrm{~A}$ & 4.29 & 7.07 & 11.23 & 6.94 \\
\hline
\end{tabular}

Simulations are based on the model in Table 1B. $\mathrm{F}=$ forest; $\mathrm{D}=$ developed (urban); $\mathrm{A}=$ agriculture; the percentages identify the amount of each land-cover class. Arithmetic differences between simulated results for the $100 \%$ forest case and observed values for forest (Table 1A) are expressions of goodness-of-fit (e.g., $\mathrm{P}_{50}=2.45_{\mathrm{obs}}$, versus $2.98_{\text {sim }}$ ). Our median values (observed and simulated) agree with the reference value of $2.3 \mathrm{~kg} / \mathrm{ha} / \mathrm{yr}$ proposed by Howarth and others (1996), and our $\mathrm{P}_{75}$ values agree with the reference value of $3.5 \mathrm{~kg} / \mathrm{ha} / \mathrm{yr}$ proposed by Meybeck (1982)

nutrient criteria on a year-in, year-out basis. For example, our simulations suggests that a $\mathrm{TN}$ nutrient criteria of $4.0 \mathrm{~kg} / \mathrm{ha} / \mathrm{yr}$ would be met 3 out of 4 years for a homogenously forested watershed, but that a $20 \%$ loss of forest would reduce the likelihood of realizing $4.0 \mathrm{~kg} / \mathrm{ha} / \mathrm{yr}$ by $25 \%$, and introduce the possibility of much higher yields (Table 4). Comparison of the nutrient targets (e.g., criteria) for the Chesapeake Bay proposed by Linker and others (1996) with the nutrient yields observed by Fisher and others (1998) in the upper Choptank River, which flows into the Chesapeake Bay, provides a real-world complement to our hypothetical example. The annual yields from the upper Choptank for 1984 and 1989 of $11.50 \mathrm{~kg} / \mathrm{ha} / \mathrm{yr}$ and $9.44 \mathrm{~kg} /$ ha/yr, respectively (Fisher and others 1998), exceeded the targets proposed by Linker and others (1996). Our results also suggest that there is little practical value in applying nutrient criteria based on reference (i.e., "pristine") conditions to watersheds dominated by urban or agriculture. There is little likelihood that annual yields in urban- and agriculture-dominated watersheds will meet nutrient criteria based on reference conditions on a year-in, year-out basis (Table 1A, Table 4).

Acknowledgments The U.S. Environmental Protection Agency (EPA), through its Office of Research and Development (ORD), funded the research. This article has been subjected to the EPA's peer and administrative review and has been approved for publication. Kurt Riitter's participation was supported by the U.S. Forest Service and the Center for Landscape Pattern Analysis. The authors thank Lisa Smith, Steve Verrill, Walter Dodds, Larry Band, and two anonymous reviewers for their helpful comments on previous versions of the paper.

\section{References}

Alexander RB, Smith RA, Schwarz GE (2000) Effect of stream channel size on the delivery of nitrogen to the Gulf of Mexico. Nature 403:758-761 
Alexander RB, Slack JR, Ludtke AS, Fitzgerald KK, Schertz TL (1998) Data from selected U.S. Geological Survey national stream water quality monitoring networks. Water Resources Research 34:2401-2405

Arnold JG, Srinivasan R, Muttiah RS, Williams JR (1998) Large-area hydrologic modeling and assessment: part I. model development. Journal of the American Water Resources Association 34:73-89

Clesceri NL, Curran SJ, Sedlak RI (1986) Nutrient loads to Wisconsin lakes: part I. Nitrogen and phosphorus export coefficients. Water Resources Bulletin 22:983-989

Beaulac MN, Reckhow KH (1982) An examination of land use nutrient export relationships. Water Resources Bulletin 18:10131024

Dodds WK, Welch EB (2000) Establishing nutrient criteria in streams. 2000. Journal of the North American Benthological Society 19:186-196

Dodds WK, Oakes RM (2004) A technique for establishing reference nutrient concentrations across watersheds effected by humans. Limnology and Oceanography: methods 2:333-341

Dodds WK, Blair JM, Hennebry GM, Koelliker JK, Ramundo R, Tate CM (1996) Nitrogen transport from tallgrass prairie watersheds. Journal of Envirionmental Quality 25:973-981

Donigian AS Jr, Imhoff JC (2002) From the Stanford Model to BASINS: 40 years of watershed modeling. ASCE Task Committee on Evolution of hydrologic Methods Through Computers. ASCE 150th Anniversary Celebration, November 3-7, 2002, Washington, DC. Available at: http://www.hspf.com/ publications.html. Last viewed March 13, 2008

Fegeas RG, Claire RW, Guptil SC, Anderson KE, Hallam CA (1983) Land use and land cover digital data. Geological Survey Circular 895-E, U.S. Geological Survey, Washington, DC

Fisher TR, Lee KY, Berndt H, Benitez JA, Norton MM (1998) Hydrology and chemistry of the Choptank river basin. Water, Air, and Soil Pollution 105:387-397

FGDC (Federal Geographic Data Committee) (2004) Federal standards for delineation of hydrologic unit boundaries; Version 2. Available at: http://www.ncgc.nrcs.usda.gov/products/datasets/ watershed/. Last viewed March 13, 2008

Frink CR (1991) Estimating nutrient exports to estuaries. Journal of Environmental Quality 20:717-724

Gassman PW, Reyes MR, Green CH, Arnold JG (2007) The soil and water assessment tool: historical development, applications, and future research directions. Transactions of the American Society of Agricultural and Biological Engineers 504:1211-1250

Gesch D, Oimen D, Greenlee S, Nelson C, Steuck M, Tyler D (2002) The National Elevation Dataset. Photogrammetric Engineering and Remote Sensing 68:5-11

Groffman PM, Law NL, Belt KT, Band LE, Fisher GT (2004) Nitrogen fluxes and retention in urban watershed ecosystems. Ecosystems 7:393-403

Homer C, Dewitz J, Fry J, Coan M, Hossain N, Larson C, Herold N, McKerrow A, VanDriel JN, Wickham JD (2007) Completion of the 2001 National Land Cover Database for the conterminous United States. Photogrammetric Engineering \& Remote Sensing 73:337-341

Howarth RW, Billen G, Swaney D, Townsend A, Jaworski N, Lajtha K, Dowling JA, Elmgren R, Caraco N, Jordan T, Berendse F, Freney J, Kudeyarov V, Murdoch P, Zhao-Liang Z (1996) Regional nitrogen budgets and riverine $\mathrm{N} \& \mathrm{P}$ fluxes for the drainages of the North Atlantic Ocean: natural and human influences. Biogeochemistry 35:75-139

Hunsaker CT, Levine DA (1995) Hierarchical approaches to the study of water quality in rivers. BioScience 45:193-203

Jones KB, Neale AC, Nash MS, Van Remortel RD, Wickham JD, Riitters KH, O'Neill RV (2001) Predicting nutrient and sediment loadings to streams from landscape metrics: a multiple watershed study from the United States mid-Atlantic Region. Landscape Ecology 16:301-312

Jordan TE, Correll DL, Weller DE (1997) Effects of agriculture on discharges of nutrients from Coastal Plain watersheds of Chesapeake Bay. Journal of Environmental Quality 26:836-848

Kemp MJ, Dodds WK (2001) Spatial and temporal patterns of nitrogen concentrations in pristine and agriculturally-influenced prairie streams. Biogeochemistry 53:125-141

Lewis WM Jr (2002) Yield of nitrogen from minimally disturbed watersheds in the United States. Biogeochemistry 57/58:375-385

Line DE, White NM, Osmond DL, Jennings GD, Mojonnier CB (2002) Pollutant export from various land uses in the upper Neuse River basin. Water Environment Research 74:100-108

Linker LC, Stigall GC, Chang CH, Donigian AS (1996) Aquatic accounting: Chesapeake Bay watershed model quantifies nutrient loads. Water Environment and Technology 8:48-52

McFarland AMS, Hauck LM (2001) Determining nutrient export coefficients and source loading uncertainty using in-stream monitoring data. Journal of the American Water Resources Association 37:223-236

McMahon G, Alexander RB, Qian S (2003) Support of total maximum daily load program using spatially referenced regression models. Journal of Water Resources Planning and Management 129:315-328

Meybeck J (1982) Carbon, nitrogen, and phosphorus transport by world rivers. American Journal of Science 282:401-450

Omernik JM (1977) Nonpoint source-stream nutrient level relationships: a nationwide study. EPA-600/3-77-105. Office of Research and Development, U.S. Environmental Protection Agency, Corvallis, OR, USA

Osborne LL, Kovacic DA (1993) Riparian vegetated buffer strips in water-quality restoration and stream management. Freshwater Biology 52:243-258

Panuska JC, and Lillie RA (1995) Phosphorus loadings from Wisconsin watersheds: recommended phosphorus export coefficients for agricultural and forested watersheds. Research Management Findings, Number 38, Bureau of Research, Wisconsin Department of Natural Resources, Madison, Wisconsin, USA, 8 pp

Paul MJ, Meyer JL (2001) Streams in the urban landscape. Annual Review of Ecology and Systematics 32:333-365

Peterjohn WT, Correll DL (1984) Nutrient dynamics in an agricultural watershed: observations on the role of a riparian forest. Ecology 65:1466-1475

Rabalais NN, Turner RE, Justić D, Dortch Q, Wiseman WJ Jr, Sen Gupta BK (1996) Nutrient changes in the Mississippi River and system responses on the adjacent Continental Shelf. Estuaries 19:386-407

Reckhow KH, Beaulac MN, Simpson JT (1980) Modeling phosphorus loading and lake response under uncertainty: a manual and compilation of export coefficients. EPA/440/5-80/011, U.S. Environmental Protection Agency, Washington, DC, USA

Rohm CM, Omernik JM, Woods AJ, Stoddard JL (2002) Regional characteristics of nutrient concentrations in streams and their application to nutrient criteria development. Journal of the American Water Resources Association 38:213-239

Shenk G, Linker L. Unpubl. Simulating the Chesapeake Bay Watershed with time-varying land use and management actions. Available at: http://www.chesapeakebay.net/pubs/subcommittee/mdsc/docShenk_timevaryinglanduse431.pdf. Last viewed April 23, 2008

Smith RA, Alexander RB, Schwarz GE (2003) Natural background concentrations of nutrients in streams and rivers of the conterminous United States. Environmental Science and Technology 37:3039-3047

Smith RA, Schwarz GE, Alexander RB (1997) Regional interpretation of water-quality monitoring data. Water Resources Research $33: 2781-2798$ 
USEPA (U.S. Environmental Protection Agency) (1997) Hydrological Simulation Program - FORTRAN: User's Manual for Version 11. EPA/600/SR-97/080. Office of Research and Development, Environmental Protection Agency, Research Triangle Park, NC, USA

USEPA (U.S. Environmental Protection Agency) (1998) National strategy for the development of regional nutrient criteria. EPA 822-R-98-002. Office of Water, U.S. Environmental Protection Agency, Washington, DC, USA

USGS (U.S. Geological Survey) (1996) Data from selected U.S. Geological Survey National Stream Water-Quality Monitoring Networks (WQN). U.S. Geological Survey Digital Data Series DDS-37, ISBN 0-607-86425-7

Vogelmann JE, Howard SM, Yang L, Larson CR, Wylie BK, Van Driel N (2001) Completion of the 1990s National Land Cover Data Set for the Conterminous United States from Landsat Thematic Mapper data and ancillary data sources. Photogrammetric Engineering and Remote Sensing 67:650-662
Vuorenmaa J, Recolainen S, Lepistö A, Kenttämies K, Kauppila P (2002) Losses of nitrogen and phosphorus from agricultural and forest areas in Finland during the 1980s and 1990s. Environmental Monitoring and Assessment 76:213-248

Waring RH, Schlesinger WH (1985) Forest ecosystems: concepts and management. Academic Press, Orlando, FL, USA

Wickham JD, Riitters KH, O'Neill RV, Reckhow KH, Wade TG, Jones KB (2000) Land cover as a framework for assessing risk of water pollution. Journal of the American Water Resources Association 36:1417-1414

Wickham JD, O'Neill RV, Riitters KH, Smith ER, Wade TG, Jones KB (2002) Geographic targeting of increases in nutrient export due to future urbanization. Ecological Applications 12:93-106

Wickham JD, Riitters KH, Wade TG, Jones KB (2005) Evaluating the relative roles of ecological regions and land-cover composition for guiding establishment of nutrient criteria. Landscape Ecology 20:791-798 